University of Nebraska - Lincoln

DigitalCommons@University of Nebraska - Lincoln

Agronomy \& Horticulture - Faculty Publications

Agronomy and Horticulture Department

2005

\title{
Environmental factors affecting seed persistence of annual weeds across the U.S. corn belt
}

\author{
Adam S. Davis \\ Michigan State University \\ John Cardina \\ Ohio State University \\ Frank Forcella \\ USDA-ARS \\ Gregg A. Johnson \\ University of Minnesota, johns510@umn.edu \\ George Kegode \\ North Dakota State University \\ See next page for additional authors
}

Follow this and additional works at: https://digitalcommons.unl.edu/agronomyfacpub

Part of the Plant Sciences Commons

Davis, Adam S.; Cardina, John; Forcella, Frank; Johnson, Gregg A.; Kegode, George; Lindquist, John L.; Luschei, Edward C.; Renner, Karen A.; Sprague, Christy L.; and Williams, Martin M. II, "Environmental factors affecting seed persistence of annual weeds across the U.S. corn belt" (2005). Agronomy \& Horticulture -- Faculty Publications. 414.

https://digitalcommons.unl.edu/agronomyfacpub/414

This Article is brought to you for free and open access by the Agronomy and Horticulture Department at DigitalCommons@University of Nebraska - Lincoln. It has been accepted for inclusion in Agronomy \& Horticulture -Faculty Publications by an authorized administrator of DigitalCommons@University of Nebraska - Lincoln. 


\section{Authors}

Adam S. Davis, John Cardina, Frank Forcella, Gregg A. Johnson, George Kegode, John L. Lindquist, Edward C. Luschei, Karen A. Renner, Christy L. Sprague, and Martin M. Williams II 


\section{Environmental factors affecting seed persistence of annual weeds across the U.S. corn belt}

\author{
Adam S. Davis ${ }^{1}$ \\ John Cardina ${ }^{2}$ \\ Frank Forcella ${ }^{3}$ \\ Gregg A. Johnson ${ }^{4}$ \\ George Kegode \\ John L. Lindquist ${ }^{6}$ \\ Edward C. Luschei ${ }^{7}$ \\ Karen A. Renner ${ }^{8}$ \\ Christy L. Sprague 9 \\ Martin M. Williams, II ${ }^{10}$ \\ ${ }^{1}$ Corresponding author. Department of Crop and \\ Soil Sciences, Michigan State University, East \\ Lansing, MI 48824; Current address: USDA-ARS \\ Invasive Weed Management Unit, Urbana, IL \\ 61801; asdavis1@uiuc.edu
}

2 Department of Horticulture and Crop Science, Ohio State University, Wooster, OH 44691

${ }^{3}$ USDA-ARS, North Central Soil Conservation Research Laboratory, Morris, MN 56267

${ }^{4}$ Department of Agronomy and Plant Genetics, University of Minnesota, Southern Research and Outreach Center, Waseca MN 56093

5 Department of Plant Sciences, North Dakota State University, Fargo, ND 58105

${ }^{6}$ Department of Agronomy and Horticulture, University of Nebraska, Lincoln, NE 68583

7 Department of Agronomy, University of Wisconsin, Madison, WI 53706

${ }^{8}$ Department of Crop and Soil Sciences, Michigan State University, East Lansing, MI 48824

9 Department of Crop Sciences, University of Illinois, Urbana, IL 61801. Current address: Department of Crop and Soil Sciences, Michigan State University, East Lansing, MI 48824

${ }^{10}$ Washington State University, Prosser, WA, 99350; Current address: USDA-ARS Invasive Weed

Management Unit, Urbana, IL 61801.

\begin{abstract}
Weed seedbanks have been studied intensively at local scales, but to date, there have been no regional-scale studies of weed seedbank persistence. Empirical and modeling studies indicate that reducing weed seedbank persistence can play an important role in integrated weed management. Annual seedbank persistence of 13 summer annual weed species was studied from 2001 through 2003 at eight locations in the north central United States and one location in the northwestern United States. Effects of seed depth placement, tillage, and abiotic environmental factors on seedbank persistence were examined through regression and multivariate ordinations. All species examined showed a negative relationship between hydrothermal time and seedbank persistence. Seedbank persistence was very similar between the two years of the study for common lambsquarters, giant foxtail, and velvetleaf when data were pooled over location, depth, and tillage. Seedbank persistence of common lambsquarters, giant foxtail, and velvetleaf from October 2001 through 2002 and October 2002 through 2003 was, respectively, $52.3 \%$ and $60.0 \%, 21.3 \%$ and $21.8 \%$, and $57.5 \%$ and $57.2 \%$. These results demonstrate that robust estimates of seedbank persistence are possible when many observations are averaged over numerous locations. Future studies are needed to develop methods of reducing seedbank persistence, especially for weed species with particularly long-lived seeds.
\end{abstract}

Nomenclature: Common lambsquarters, Chenopodium album L. CHEAL; giant foxtail, Setaria faberi Herrm. SETFA; velvetleaf, Abutilon theophrasti Medik. ABUTH.

Key words: Hydrothermal time, redundancy analysis, seedbank persistence, soil properties, soil seedbank, weed dynamics.
The importance of weed seedbank persistence to farmers is aptly described by the old adage, "One year's seeding, seven years' weeding." The importance for annual weed populations is that seedbank persistence is a buffer against local extinction in unfavorable years (Fenner and Thompson 2005) via diverse dormancy regulation mechanisms (Benech-Arnold et al. 2000). Seedbank density is increased greatly during conditions favorable to weed growth or as a result of poor weed management. Following seed production pulses, the seeds stored in the soil represent the primary source of new weed infestations in subsequent years (Cou- sens and Mortimer 1995). Although seeds of some weed species, such as kochia [Kochia scoparia (L.) Schrad.], persist in the soil seedbank for only $1 \mathrm{yr}$, many weed species have seeds that persist in the soil seedbank for decades (Burnside et al. 1996; Thompson et al. 1997). Physiological mechanisms involved in the formation of persistent seedbanks include dormancy (Benech-Arnold et al. 2000), dispersal (Fenner and Thompson 2005), heterogeneity of seed biotypes (Harrison et al. 2003), and deterioration-resistance compounds in the seed coat (Kremer 1986). Farmer experience as well as empirical and modeling studies (Davis et al. 2004; 
TABLE 1. Annual and subannual seedbank persistence of 13 weed species of the U.S. corn belt, averaged over location, burial depth, and tillage.

\begin{tabular}{|c|c|c|c|c|c|c|c|c|c|c|c|c|c|}
\hline \multirow{3}{*}{ Species } & \multirow{3}{*}{ Burial year ${ }^{\mathrm{a}}$} & \multicolumn{12}{|c|}{ Burial period } \\
\hline & & \multicolumn{12}{|c|}{ October through April $\longrightarrow$ April through October $\longrightarrow-$ October through October } \\
\hline & & $\% \mathrm{o}^{\mathrm{b}}$ & SEM & $n$ & Sites $^{\mathrm{c}}$ & $\%$ & SEM & $n$ & Sites & $\%$ & SEM & $n$ & Sites \\
\hline \multirow[t]{2}{*}{ ABUTH $^{d}$} & $2001-2002$ & 77.0 & 0.92 & 371 & $1-5,7-9$ & 58.6 & 1.9 & 200 & $1-4,9$ & 57.5 & 1.8 & 267 & $1-4,7-9$ \\
\hline & $2002-2003$ & 74.7 & 1.4 & 233 & $1-3,6-8$ & 56.9 & 2.5 & 146 & $1-3$ & 57.2 & 2.2 & 220 & $1-3,6-8$ \\
\hline \multirow[t]{2}{*}{ AMARE } & $2001-2002$ & 84.5 & 1.9 & 90 & 2 & 70.6 & 2.6 & 85 & 2 & 59.3 & 2.7 & 90 & 2 \\
\hline & $2002-2003$ & 57.9 & 3.6 & 38 & 2 & 57.1 & 4.6 & 39 & 2 & 18.6 & 3.3 & 36 & 2 \\
\hline \multirow{2}{*}{ AMATA } & 2001-2002 & 61.6 & 3.4 & 42 & 1 & 41.0 & 2.2 & 47 & 1 & 39.1 & 2.3 & 48 & 1 \\
\hline & $2002-2003$ & 95.3 & 0.8 & 48 & 1 & 84.9 & 2.8 & 47 & 1 & 74.9 & 2.8 & 48 & 1 \\
\hline \multirow[t]{2}{*}{ AMBTR } & $2001-2002$ & 36.6 & 4.3 & 42 & 1 & 31.2 & 3.1 & 19 & 1 & 13.5 & 2.1 & 30 & 1 \\
\hline & $2002-2003$ & 10.1 & 1.6 & 27 & 1 & 47.8 & 6.1 & 21 & 1 & 5.2 & 1.4 & 28 & 1 \\
\hline \multirow[t]{2}{*}{ CHEAL } & $2001-2002$ & 73.2 & 0.9 & 330 & $1-5,8,9$ & 66.3 & 1.3 & 240 & $1-3,9$ & 52.3 & 1.8 & 264 & $1-5,8,9$ \\
\hline & $2002-2003$ & 75.8 & 1.4 & 194 & $1-3,6,8$ & 70.9 & 2.4 & 163 & $1-3$ & 60.0 & 2.5 & 189 & $1-3,6,8$ \\
\hline \multirow[t]{2}{*}{ ERIVI } & $2001-2002$ & 44.7 & 3.6 & 43 & 1 & 52.6 & 1.2 & 48 & 1 & 19.4 & 2.2 & 36 & 1 \\
\hline & $2002-2003$ & 13.3 & 4.6 & 32 & 1 & 73.6 & 5.1 & 39 & 1 & 24.6 & 4.2 & 44 & 1 \\
\hline HELAN & $2001-2002$ & 72.5 & 7.1 & 11 & 5 & - & - & - & - & - & - & - & - \\
\hline PANMI & $2001-2002$ & 83.0 & 2.0 & 71 & 9 & 70.9 & 3.1 & 38 & 9 & 58.4 & 2.3 & 38 & 9 \\
\hline POLPE & 2001-2002 & 46.0 & 7.3 & 11 & 5 & - & - & - & - & - & - & - & - \\
\hline SALRE & $2002-2003$ & 65.0 & 6.7 & 12 & 6 & - & - & - & - & 58.2 & 4.5 & 12 & 6 \\
\hline \multirow[t]{2}{*}{ SETFA } & $2001-2002$ & 72.4 & 1.4 & 309 & $1-5,9$ & 26.5 & 1.7 & 236 & $1-3,9$ & 21.3 & 2.2 & 230 & $1-4,9$ \\
\hline & $2002-2003$ & 73.3 & 2.2 & 157 & $1-3$ & 31.6 & 2.6 & 141 & $1-3$ & 21.8 & 2.1 & 144 & $1-3$ \\
\hline \multirow[t]{2}{*}{ SETLU } & $2001-2002$ & 75.8 & 1.7 & 91 & 8,9 & - & - & - & - & - & - & - & - \\
\hline & $2002-2003$ & 72.0 & 2.9 & 36 & 6,8 & - & - & - & - & - & - & - & - \\
\hline SORVU & 2001-2002 & 49 & 7.3 & 12 & 5 & - & - & - & - & - & - & - & - \\
\hline
\end{tabular}

${ }^{a}$ In the 2001-2002 burial year, seeds were buried from October 2001 through April 2002; April 2002 through October 2002; and October 2001 through October 2002. The same pattern applied to the 2002-2003 burial year.

$\mathrm{b}$ The column units for each burial period are \%, mean percent seedbank persistence; SEM, standard error of the mean; $n$, the number of observations; and site, the locations represented for each mean seed-persistence value.

${ }^{\mathrm{c}}$ Key to seed burial: 1, Urbana, IL; 2, Hickory Corners, MI; 3, Morris, MN; 4, Waseca, MN; 5, Mead, NE; 6, Fargo, ND; 7, Wooster, OH; 8, Prosser, WA; 9, Madison, WI.

d Explanation of BAYER codes: ABUTH, velvetleaf; AMARE, redroot pigweed; AMATA, common waterhemp; AMBTR, giant ragweed; CHEAL, common lambsquarters; ERIVI, wooly cupgrass; HELAN, common sunflower; PANMI, wild proso millet; POLPE, ladysthumb; SALRE, lanceleaf sage; SETFA, giant foxtail; SETLU, yellow foxtail; SORVU, shattercane.

Jordan et al. 1995; Taylor and Hartzler 2000) all point to the importance of managing weed seedbanks for successful long-term weed management.

A serious limitation of current scientific knowledge to support strategic management of weed seedbanks is the narrow applicability of much seedbank persistence data. There is little uniformity in protocols (Gallandt et al. 2004; Lewis 1973; Telewski and Zeevaart 2002; Teo-Sherrell et al. 1996), study locations, or species. Although seedbank persistence has been described for many species (Burnside et al. 1996; Thompson et al. 1997), there is little overlap between study methods, making a meta-analysis of the literature to develop broader inferences impractical.

With these limitations in mind, the NC202 Regional Research Committee on weed biology initiated a coordinated, multilocation, 2-yr study of weed seedbank persistence. The committee's objective was to increase our understanding of the relative importance of burial location, burial year, species, primary tillage, and seed burial depth on annual persistence of weed seeds in the soil seedbank.

\section{Materials and Methods}

\section{Study Design}

Two types of data sets were collected for this study: extensive and intensive. The extensive data set was primarily for observing the range of variation in seedbank persistence for the 13 species represented in the study. In this data set, collaborators examined soil seedbank persistence of seeds of annual weed species of local interest buried at $0,2.5,5$, or $10 \mathrm{~cm}$. These depths were selected because they all lie within the zone from which weed seeds can successfully germinate (Benvenuti et al. 2001). The weed species and burial locations for the extensive data set are listed in Table 1. All seeds were buried within plots of corn (Zea mays L.) managed according to local best management practices. Specific management practices were not considered as experimental factors in the analysis of the extensive data set. At each location, seeds were buried in mesh bags (see below for greater detail on seed burial and characterization methods) arranged in a randomized complete block design with at least four replications of the study for each species.

The intensive data set focused only on the seedbank persistence of common lambsquarters, velvetleaf, and giant foxtail. All locations included at least one of these species in field studies, and many had two or more (Table 1). Within the intensive data set, the Illinois, Michigan, and Morris, $\mathrm{MN}$, locations formed a full factorial of burial year (2001 vs. 2002), burial depth $(0,2.5$, and $10 \mathrm{~cm}$ ), and tillage (no till $[\mathrm{NT}]$ vs. conventional tillage $[\mathrm{CT}])$ for all three species.

\section{Experimental Locations}

Nine university research farms in eight states were used as seed burial sites over the course of the experiment. Seed 
burial locations included Urbana, IL (lat $40^{\circ} 05^{\prime} \mathrm{N}$, long $88^{\circ} 13^{\prime} \mathrm{W}$ ), Morris, $\mathrm{MN}$ (lat $45^{\circ} 41^{\prime} \mathrm{N}$, long $95^{\circ} 47^{\prime} \mathrm{W}$ ), Waseca, $\mathrm{MN}$ (lat $44^{\circ} 10^{\prime} \mathrm{N}$, long $93^{\circ} 50^{\prime} \mathrm{W}$ ), Hickory Corners, MI (lat $42^{\circ} 24^{\prime} \mathrm{N}$, long $85^{\circ} 24^{\prime} \mathrm{W}$ ), Fargo, ND (lat $46^{\circ} 52^{\prime} \mathrm{N}$, long $96^{\circ} 48^{\prime} \mathrm{W}$ ), Mead, NE (lat $41^{\circ} 14^{\prime} \mathrm{N}$, long $96^{\circ} 29^{\prime} \mathrm{W}$ ), Wooster, $\mathrm{OH}$ (lat $40^{\circ} 47^{\prime} \mathrm{N}$, long $81^{\circ} 55^{\prime} \mathrm{W}$ ), Patterson, WA (lat $45^{\circ} 46^{\prime} \mathrm{N}$, long $119^{\circ} 36^{\prime} \mathrm{W}$ ), and Madison, WI (lat $43^{\circ} 7^{\prime} \mathrm{N}$, long $\left.89^{\circ} 42^{\prime} \mathrm{W}\right)$. Soil types for these locations were, respectively, Catlin silt loam (Oxyaquic Argiudoll; 7\% sand, $68 \%$ silt, $25 \%$ clay, $4.2 \%$ soil organic carbon [OC], and $\mathrm{pH}$ 7.2); Aastad clay loam (fine-loamy mixed Pachic Udic Haploboroll; $51 \%$ sand, $29 \%$ silt, $20 \%$ clay, $6 \%$ OC, and $\mathrm{pH}$ of 6.4); Webster clay loam (Typic Haplaquoll; $30 \%$ sand, $40 \%$ silt, $30 \%$ clay, $6.3 \%$ OC, and $\mathrm{pH} 6.3$ ); Kalamazoo silt loam (Typic Hapludalf; 43\% sand, 40\% silt, 17\% clay, $1.1 \% \mathrm{OC}$, and $\mathrm{pH}$ 6.7); Fargo-Ryan association silty clay (Typic Epiaquert Typic Natraquert; $4 \%$ sand, 42\% silt, $54 \%$ clay, 5.4\% OC, and $\mathrm{pH} 7.5$ ); Sharpsburg silty clay loam (fine, montmorillonitic mesic Typic Argiudoll 3.5\% $\mathrm{OC}$, and $\mathrm{pH}$ 6.5); Wooster loam (fine, mixed, Typic Fragiaqualf; $11 \%$ sand, $75 \%$ silt, and $14 \%$ clay, $2.9 \%$ OC, $\mathrm{pH}$ 6.5); Quincy sand (mixed mesic Xeric Torripsamment; $75 \%$ sand, $15 \%$ silt, $10 \%$ clay, $0.3 \% \mathrm{OC}$, and $\mathrm{pH} 7.0$ ); and Plano silt loam (fine silty, mixed mesic Typic Argiudoll; $70 \%$ sand, $20 \%$ silt, $10 \%$ clay, $4.1 \%$ OC, and $\mathrm{pH} 5.8$ ).

\section{Seed Burial, Recovery, and Characterization}

All seeds were collected locally at each participating site and buried within the same year of collection. Initial seed viability for each seed lot was determined by moderate forceps pressure. Subsamples of accessions indicated a strong correlation (greater than $83 \%$ for 4 of 13 species and greater than $90 \%$ for the remaining 9 species) between the forceps test and viability as determined by tetrazolium testing (Peters 2000). One hundred viable seeds of each species were placed separately in synthetic cloth bags with a $0.25-\mathrm{mm}^{2}$ mesh. No soil was included in the bags. These formed the experimental units of this study. Bags were buried at $0,2.5$, 5 , or $10 \mathrm{~cm}$, and were identified by permanent tags. Cylindrical probes were used to create holes $10 \mathrm{~cm}$ in diameter to the desired burial depth. After a seed burial bag was placed in its hole, the plug formed by the probe was replaced in the hole, flush with the surrounding soil surface. Participants were careful not to let the soil plug crumble to avoid changing the bulk density of the soil covering the seeds. In cases where the plug did crumble, the soil was tamped down after being restored to the hole, to attain a similar level of compaction to the surrounding soil. Depending on location, weed seeds were buried for one or more of the following target periods in 2001 and 2002: October 15, 2001, through April 14, 2002; April 15, 2002, through October 14, 2002; October 15, 2002, through October 14, 2003; April 15, 2003, through July 14, 2003; and July 15, 2003, through October 14, 2003. These periods varied by a few days at some sites and years because of inclement weather, labor constraints, etc. These time periods were chosen because they approximate the times of the presence and absence of corn. That is, seedbed preparation and planting typically occurs in mid- to late-April through early May, and grain harvesting and autumn tillage usually occurs in midto late-October.

Variation in site replication among burial periods (Table
1) was influenced by the resources that different participants were able to devote to the project. For the extensive data set, most institutions were able to bury seeds for the October through April, April through October, and October through October time periods. For locations that did not measure annual seedbank persistence by means of a year-long burial period, this parameter was estimated as the product of the proportion of seeds surviving each of the subannual burial periods comprising the annual burial period. For example, at a location where seeds were buried from October 15, 2001, through April 14, 2002; and April 15, 2002, through October 14, 2002, the product of the proportion of weed seeds of a given species surviving each of these subannual burial periods would have been used to estimate annual seedbank persistence.

Weed seed bags were recovered from the field by using a trowel to loosen the soil around the bag, and pulling gently on a line attached to the bag. After recovery, weed seed bags were stored in sealed polyethylene bags at $4 \mathrm{C}$ until processing. Processing consisted of carefully opening bags and examining each seed visually. Obviously decayed or germinated seeds were separated and seemingly whole seeds were probed with fine-tipped forceps. Only firm seeds were considered to be viable.

Seedbank persistence, the total proportion of viable seeds remaining in the seed lot, was determined as the number of viable seeds remaining divided by the number of viable seeds that were buried. In situ measurements of seed losses to germination were not possible at all locations and time periods; therefore, no attempt was made to separate overall losses of viable seed into losses due to germination and losses due to mortality.

\section{Environmental Variables}

For each burial location, data were obtained for the following environmental variables: latitude, longitude, elevation, soil organic matter, $\%$ sand, $\%$ silt, $\%$ clay, and daily weather data (precipitation, air temperature, solar radiation, relative humidity, and wind speed). The weather and soil data were used to estimate soil temperature and matric potential at 0-, 2.5-, 5-, and 10-cm depths for the seed burial periods described above using the SHAW 2.3 model (Flerchinger 2000). Values for soil temperature and matric potential estimated with the SHAW model showed a strong positive correlation $(r=0.82, \mathrm{P}<0.001)$ with direct measurements made in 2001 and 2002 at Hickory Corners, MI.

The soil matric potential and soil temperature data were then used to calculate hydrothermal time (Bradford 2002; Grundy et al. 2000) as follows:

$$
\theta_{k}=\sum_{i}^{n}\left(T_{i}-T_{b}\right) \text { for } \psi_{i} \text { for } \psi_{i}>\psi_{b}
$$

where $\theta$ represents hydrothermal time, $k$ represents the burial period, $n$ represents the number of days in the simulation, $T_{i}$ represents the daily soil temperature in degrees $\mathrm{C}$ at a given depth, $T_{b}$ represents the base temperature in degrees $\mathrm{C}, \psi_{i}$ represents the soil matric potential in $\mathrm{kPa}$ at a given depth, and $\psi_{b}$ represents the base soil matric potential for a species. We used soil matric potential as a threshold for summing thermal time rather than as a continuous variable (Bradford 2002; Grundy et al. 2000) because there are no 
TABle 2. Parameters describing the linear regression of hydrothermal time ${ }^{\mathrm{a}}$ against seedbank persistence for 13 weed species of the north-central United States, averaged over location, burial depth, and tillage. ${ }^{\mathrm{b}}$

\begin{tabular}{llccrr}
\hline Species & $\beta_{0}{ }^{c}$ & \multicolumn{1}{c}{$\beta_{1}$} & $R^{2}$ & P value & \multicolumn{1}{c}{$n$} \\
\hline ABUTH & 1.1 & $-2.3 \times 10^{-4}$ & 0.18 & $<0.001$ & 1,624 \\
AMARE & 1.0 & $-1.5 \times 10^{-4}$ & 0.07 & $<0.001$ & 378 \\
AMATA & 1.2 & $-6.0 \times 10^{-4}$ & 0.26 & $<0.001$ & 280 \\
AMBTR & 0.54 & $-2.4 \times 10^{-4}$ & 0.03 & 0.019 & 167 \\
CHEAL & 1.1 & $-1.5 \times 10^{-4}$ & 0.08 & $<0.001$ & 1,533 \\
ERIVI & 0.91 & $-7.2 \times 10^{-4}$ & 0.20 & $<0.001$ & 241 \\
HELAN & 1.1 & $-5.4 \times 10^{-3}$ & 0.06 & 0.15 & 21 \\
PANMI & 1.1 & $-4.7 \times 10^{-5}$ & 0.01 & 0.14 & 160 \\
POLPE & 0.73 & $-2.0 \times 10^{-3}$ & 0.04 & 0.39 & 23 \\
SALRE & 0.94 & $-6.7 \times 10^{-5}$ & 0.02 & 0.48 & 24 \\
SETFA & 1.02 & $-4.2 \times 10^{-4}$ & 0.35 & $<0.001$ & 1,272 \\
SETLU & 0.93 & $-9.4 \times 10^{-5}$ & 0.02 & 0.005 & 374 \\
SORVU & 0.77 & $-4.9 \times 10^{-3}$ & 0.06 & 0.15 & 23 \\
\hline
\end{tabular}

${ }^{a}$ Base soil temperature $=5 \mathrm{C}$; base soil matric potential $=-200 \mathrm{kPa}$.

b See Table 1 for locations at which seedbank persistence was measured for each weed species.

${ }^{c}$ All regressions were of the form arcsine (proportion of seeds persisting $)^{0.5}=\beta_{0}+\beta_{1} \times$ hydrothermal time, where $\beta_{0}$ represents the y-intercept, and $\beta_{1}$ represents the slope of the regression line.

d Explanation of BAYER codes: ABUTH, velvetleaf; AMARE, redroot pigweed; AMATA, common waterhemp; AMBTR, giant ragweed; CHEAL, common lambsquarters; ERIVI, wooly cupgrass; HELAN, common sunflower; PANMI, wild proso millet; POLPE, ladysthumb; SALRE, lanceleaf sage; SETFA, giant foxtail; SETLU, yellow foxtail; SORVU, shattercane.

data yet available to describe the nature of the relationship between soil matric potential and soil temperature as they relate to seedbank persistence, and we did not want to introduce an explicit assumption about this relationship into the model. In summary, hydrothermal time accumulated as thermal time, but only when $\psi_{i}$ was $>\psi_{b}$.

Hydrothermal time was modeled against overall seedbank persistence, without distinguishing between seed losses to germination and decay. Because hydrothermal time has not previously been used as an explanatory variable for persistence of seeds in the soil seedbank, we used a factorial combination of values for $T_{b}(1$ and $5 \mathrm{C})$ and $\psi_{b}(-30,-200$, and $-1,500 \mathrm{kPa}$ or no restriction [thermal time only]) in preliminary regression analyses and reported results for the combination of variables that gave the greatest value of $R^{2}$ $\left(T_{b}=5 \mathrm{C}\right.$ and $\psi_{b}=-200 \mathrm{kPa}$, for all species).

\section{Data Analysis}

Means, standard errors, and number of observations were calculated for seedbank persistence for each of the 13 study species in the extensive data set (Table 1). A linear regression (Neter et al. 1996) of $\theta_{k}$ against $\sin ^{-1}(x)^{0.5}$-transformed seedbank persistence data (Underwood 1997) was fit for each species over all burial periods and locations (Table 2). Following linear regression, redundancy analysis (RDA) was performed for ABUTH, CHEAL, and SETFA entries in the extensive data set. RDA is a form of multivariate ordination in which ordination axis scores are constrained to be linear combinations of measured environmental variables (Økland 1996; ter Braak and Smilauer 2002). Environmental variables in this analysis included: $\theta_{k}$, soil organic matter, latitude, longitude, bulk density, $\%$ sand, $\%$ clay and seed burial depth. This analysis was performed as a forward stepwise procedure with a criterion of $\mathrm{P}<0.05$ to enter, and $\mathrm{P}>$ 0.05 to exit.

The modified Levene's test for homogeneity of error variances was performed on the intensive data set before analysis of variance. This test indicated that error variances were not constant across species but were constant across burial periods and burial locations. Within the intensive data set, general linear models including terms for burial period, burial location, replication, burial depth, and tillage were fit to $\operatorname{arcsine}^{-1}(x)^{0.5}$-transformed seedbank persistence data for each species using the general linear model (GLM) subroutine of SYSTAT $11.0^{1}$. Terms for burial period and replication were treated as random factors, whereas terms for location, depth, and tillage were treated as fixed factors. Replication was nested within the burial period by burial location interaction term. Appropriate $F$-tests were constructed for each term in the GLM models using E\{MS\} tables (Neter et al. 1996). Inspection of residuals indicated that assumptions of normality and constant variance were satisfied. Post hoc Bonferroni-corrected multiple-comparison tests were used for subsequent mean separations (Neter et al. 1996). Finally, within years, variance in seedbank persistence for each species was partitioned into orthogonal components by location, depth, tillage, and pure error (Gotelli and Ellison 2004).

\section{Results and Discussion}

\section{Variation in Annual Seedbank Persistence}

\section{Within and Between Locations}

Common lambsquarters, giant foxtail, and velvetleaf were the only species within the extensive data set that were represented in two or more locations within the annual burial period. Therefore, data for only these species will be presented in this section. Data reported in this section are averaged over burial depth.

A large amount of variation in annual seedbank persistence among locations was observed, with 6-, 19-, and 17fold differences between minimum and maximum values for giant foxtail, common lambsquarters, and velvetleaf, respectively (Figure 1). Giant foxtail annual seedbank persistence ranged from $7 \%$ at Morris, $\mathrm{MN}$, in 2001 to $42 \%$ at Urbana, IL, in 2001. Five of eight site-years for giant foxtail persistence were below $20 \%$. In contrast, annual seedbank persistence of common lambsquarters and velvetleaf was greater and also had greater variability among locations. Common lambsquarters annual seedbank persistence ranged from 5\% at Hickory Corners, MI, in 2002 to $95 \%$ at Patterson, WA, in 2002. Velvetleaf annual seedbank persistence ranged from $5 \%$ at Hickory Corners, MI, in 2002 to $88 \%$ at Urbana, IL, in 2002. Seven of 11 site-years for common lambsquarters seedbank persistence and 8 of 13 site-years for velvetleaf seedbank persistence were greater than the maximum value for giant foxtail seedbank persistence. Giant foxtail is known to form less-persistent seedbanks than velvetleaf or common lambsquarters (Buhler and Hartzler 2001; Burnside et al. 1996; Thompson et al. 1997). One notable feature of these results, however, is the relatively large number of site-years for common lambsquarters (4 of 11) and velvetleaf (5 of 13) with seedbank persistence of $40 \%$ or less. Our study methods did not allow us to determine what fraction of the $60 \%$ or more seeds that did not persist were lost to germi- 


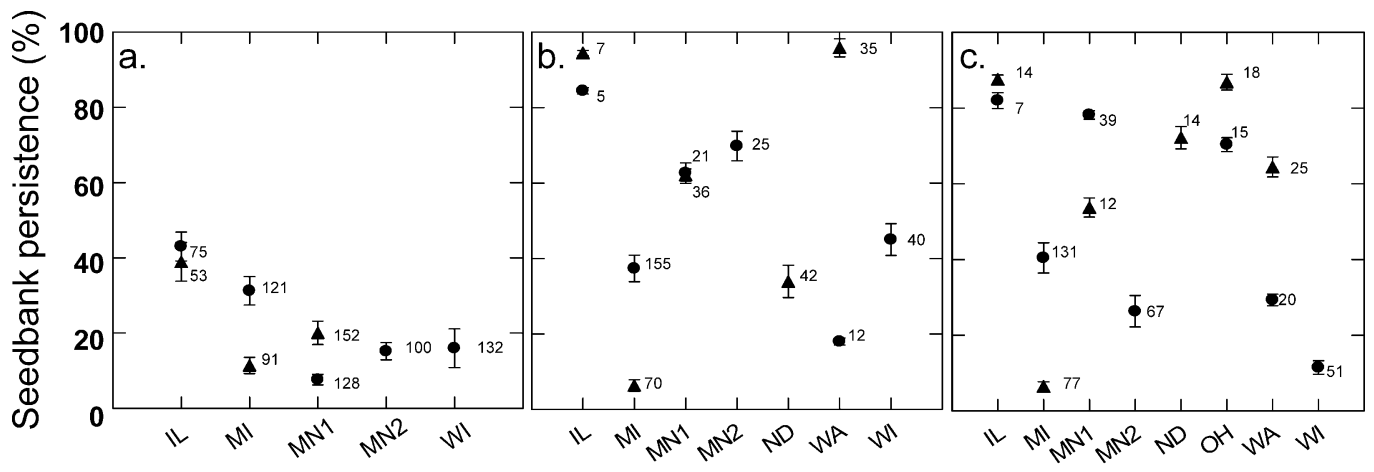

Burial location

FIGURE 1. Annual weed seedbank persistence for giant foxtail (a), common lambsquarters (b), and velvetleaf (c), by burial location. Black triangles represent the October 15, 2001, through October 14, 2002, burial period, whereas black circles represent the October 15, 2002, through October 14, 2003, burial period. Abbreviations for burial locations: IL, Urbana, IL; MI, Hickory Corners, MI; MN1, Morris, MN; MN2, Waseca, MN; ND, Fargo, ND; OH, Wooster, OH; WA, Patterson, WA; and WI, Madison, WI. Vertical bars represent \pm 1 standard error of the mean. Numbers accompanying each symbol give the coefficient of variation of the mean.

nation as opposed to mortality. Nonetheless, it appears that species with seeds that have the potential to remain viable for decades in the soil seedbank can display lower-than-average seedbank persistence under certain conditions. Environmental factors that may affect seedbank persistence are examined later in this paper.

Certain burial locations showed less variability in data between years than others. For example, Urbana, IL, and Morris, MN, tended to have more consistent values for seedbank persistence between years for all three weed species than Hickory Corners, MI. Differences in seedbank persistence between years for giant foxtail, common lambsquarters, and velvetleaf were, respectively, 11,12 , and $7 \%$ in Urbana, IL, and $100,1.6$, and $44 \%$ in Morris, MN, compared with 181, 660, and 700\% in Hickory Corners, MI (Figure 1).

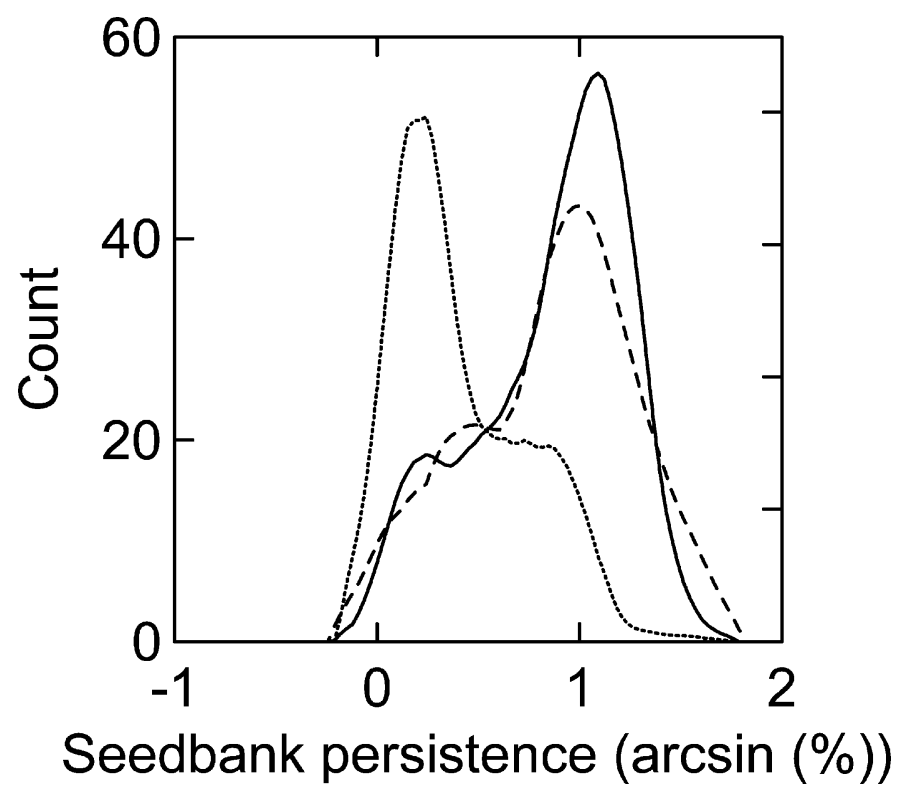

Figure 2. Nonparametric Gaussian kernel distribution functions for giant foxtail (dotted line), common lambsquarters (dashed line), and velvetleaf (solid line) arcsine $(x)^{0.5}$-transformed values of annual seedbank persistence. Data are averaged across locations. The $y$-axis variable "count" represents the number of observations at a given level of seedbank persistence.
Coefficients of variation for individual site-years tended to be greater for giant foxtail than for common lambsquarters or velvetleaf (Figure 1). One exception to this trend was for the MI data, which had coefficients of variation for all three species that were consistently higher in both years than for most other site-years. Several factors that may have led to the large coefficients of variation for Hickory Corners, MI, included: (1) many more observations for this site than other sites, (2) data for this site were averaged over several corn management systems, and (3) soil properties for this location were highly heterogeneous (Robertson et al. 1997).

\section{Across Locations}

In contrast to the large amount of variability in seedbank persistence observed among locations and between years within many of the locations, values of mean seedbank persistence pooled across locations were remarkably stable between years for common lambsquarters, giant foxtail, and velvetleaf (Table 1). With one exception (yellow foxtail [Setaria glauca (L.) Beauv.]), estimates of mean seedbank persistence pooled across locations for weed species with less than 100 observations, such as redroot pigweed (Amaranthus retroflexus L.), common waterhemp (Amaranthus rudis Sauer), giant ragweed (Ambrosia trifida L.), and wooly cupgrass [Eriochloa villosa (Thumb.) Kunth], varied widely between years. These results show the central limit theorem (Gotelli and Ellison 2004) in action: when a large number of observations are used to develop estimates of a mean, the predictions are more robust. Estimates of seedbank persistence pooled across locations provide a global view of seed characteristics for a given species, averaged over numerous sources of environmental variability. The distribution of seedbank persistence values for forbs tended to be skewed to the left, with long lower tails, whereas the distributions for grasses tended to be skewed to the right, with long upper tails (data not shown). Giant foxtail, common lambsquarters, and velvetleaf seedbank persistence distributions, fitted with a nonparametric Gaussian kernel function, ${ }^{1}$ were typical of the two groups (Figure 2). The kernel function fit the data for these species well, with $R^{2}$ values of $0.82,0.90$, and 0.88 for common lambsquarters, giant foxtail, and vel- 
vetleaf, respectively, and $\mathrm{P}<0.001$ for all three species. The general difference in distribution shapes between the grass and forb species is consistent with observations that grass species tend to form transient seedbanks compared with those of forb species (Thompson et al. 1997).

\section{Environmental Factors Affecting Weed Seedbank Persistence}

\section{Abiotic Site Characteristics}

Given the utility of hydrothermal time in predicting recruitment from the weed seedbank (Bradford 2002; Forcella et al. 1997; Grundy et al. 2000) and given that our methodology confounded seed losses to recruitment with seed losses to mortality, we chose to examine the relationship between hydrothermal time and seed persistence as a possible means of explaining differences in seedbank persistence across locations. We acknowledge that variation in seedling recruitment may have driven much of the relationship between hydrothermal time and seedbank persistence. A linear regression of hydrothermal time against $\operatorname{arcsine}(x)^{0.5}$-transformed seed persistence was fit, by species, for burial periods and locations (Table 2). A factorial combination of values for $T_{b}(1$ and $5 \mathrm{C})$ and $\psi_{b}(-30,-200$, and $-1,500 \mathrm{kPa}$ or no restriction (thermal time only)) used in calculating hydrothermal time were investigated for all species. The combination of $T_{b}=5$ and $\psi_{b}=-200 \mathrm{kPa}$ consistently gave the highest $R^{2}$ values in regressions for all species (data not shown); therefore, the regressions reported in Table 2 use these base values in calculating hydrothermal time.

Eight of the 13 species examined in this study showed a significant negative relationship between hydrothermal time and seedbank persistence (Table 2). The strongest regression was for giant foxtail, in which hydrothermal time explained $35 \%$ of the variation in seedbank persistence across locations. The weakest significant regression was for giant ragweed $\left(R^{2}=0.03\right)$, for which data were collected only in Urbana, IL. The remaining five species all had negative values for $\beta_{1}$, the slope of the regression line, but the slopes were not significantly different from zero. Because these species were represented by relatively few observations gathered within a single location, it is unclear whether the regression slopes were not significant because there was truly no relationship between hydrothermal time and seedbank persistence for these species, or whether there was simply not enough variability in the data because of low site-years to develop a strong regression.

The observed relationship between hydrothermal time and seedbank persistence within a species is useful because it helps to explain a portion of the variation in seedbank persistence across sites. Adding a soil moisture threshold for calculating thermal time increased $R^{2}$ values almost twofold for most of the species studied, and simply regressing seedbank persistence against number of days that the seeds were buried yielded $R^{2}$ values that were five times smaller than those for the regression against hydrothermal time (data not shown). These results are consistent with the importance of soil temperature and moisture in controlling seedling recruitment (Bradford 2002) and the breakdown of plant residues by soil microbes (Tate 1987). In one of the few controlled investigations of the role of soil moisture in losses from the soil seedbank due to fungal decomposition (Schafer

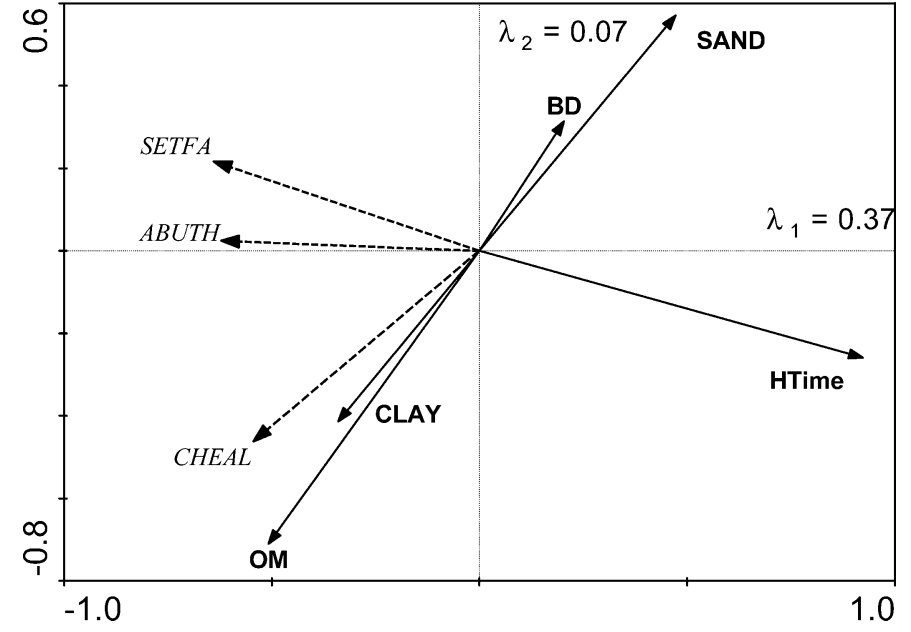

FigURE 3. Redundancy analysis (RDA) of seedbank persistence of common lambsquarters (CHEAL), giant foxtail (SETFA), and velvetleaf (ABUTH) for all burial periods and locations in relation to six environmental variables. Abbreviations for environmental variables are as follows: $\mathrm{H}$ Time, hydrothermal time; OM, \% soil organic carbon; BD, bulk density; and SAND and CLAY represent \% sand and \% clay in study soils, respectively. The proportion of variation explained by each of the RDA axes is represented by $\lambda_{1}$ and $\lambda_{2}$, the eigenvalues for RDA axes 1 and 2 . The length of solid arrows represents the relative strength of the linear relationship between environmental variables and seedbank persistence. The direction of the solid arrows, relative to the direction of the dashed arrows (seedbank persistence for a given species), shows the impact of different environmental variables on the seedbank persistence of different species.

and Kotanen 2003), increases in soil moisture led to increased seed decay by fungi for all four perennial grass species studied.

Even in the strongest regression between hydrothermal time and seedbank persistence, for giant foxtail, $65 \%$ of the variation across locations remained unexplained. This may have been because of the influence of other abiotic variables, such as soil physical and chemical properties. To examine the relative importance of other environmental variables, compared with hydrothermal time, in explaining seedbank persistence across locations, we performed an RDA on seedbank persistence of common lambsquarters, giant foxtail, and velvetleaf (Figure 3). The pool of environmental variables comprising this multivariate multiple regression technique (ter Braak and Smilauer 2002) included soil particlesize fractions, soil bulk density, percentage of soil organic matter, soil $\mathrm{pH}$, latitude, longitude, elevation, seed burial depth, and hydrothermal time. Only hydrothermal time, bulk density, \% sand, \% clay, and \% OC were retained in the fitted model. The first RDA axis was most strongly associated with hydrothermal time $(r=0.66)$ and explained $37 \%$ of the variability in the data $\left(\lambda_{1}=0.37\right)$. The vectors indicating the direction of the fitted, steepest increase of seedbank persistence values for giant foxtail and velvetleaf both showed a strong negative association with hydrothermal time. The vector for common lambsquarters seedbank persistence was only weakly associated with hydrothermal time, consistent with the univariate linear regression results for this species. Seedbank persistence of common lambsquarters was more strongly associated with \% clay and \% soil OC, which, in turn, were more closely associated with axis 2 than axis 1 . The strong, positive association between soil OC and seedbank persistence of common lambsquarters $(r=0.53)$ lends support to the hypothesis that high soil C: 
TABle 3. Effect of burial location, seed burial depth, and primary tillage on annual seedbank persistence of velvetleaf, common lambsquarters, and giant foxtail.

\begin{tabular}{|c|c|c|c|c|c|c|}
\hline \multirow[b]{3}{*}{ Factor } & \multicolumn{6}{|c|}{ Weed species } \\
\hline & \multicolumn{2}{|c|}{ Velvetleaf } & \multicolumn{2}{|c|}{$\begin{array}{c}\text { Common } \\
\text { labmsquarters }\end{array}$} & \multicolumn{2}{|c|}{ Giant foxtail } \\
\hline & 2001 & 2002 & 2001 & 2002 & 2001 & 2002 \\
\hline
\end{tabular}

\begin{tabular}{|c|c|c|c|c|c|c|}
\hline \multicolumn{7}{|c|}{ Location } \\
\hline IL & $82 c^{b}$ & $87 \mathrm{c}$ & $85 \mathrm{~cd}$ & $95 \mathrm{~d}$ & $45 \mathrm{~b}$ & $33 \mathrm{ab}$ \\
\hline MI & $35 \mathrm{~b}$ & $5 \mathrm{a}$ & $39 \mathrm{~b}$ & $5 a$ & $28 \mathrm{ab}$ & $10 \mathrm{a}$ \\
\hline $\mathrm{MN}$ & $80 \mathrm{c}$ & $54 \mathrm{~b}$ & $58 \mathrm{bc}$ & $65 c$ & $8 \mathrm{a}$ & $18 \mathrm{ab}$ \\
\hline SEM & \multicolumn{2}{|c|}{4} & \multicolumn{2}{|c|}{12} & \multicolumn{2}{|c|}{20} \\
\hline \multicolumn{7}{|c|}{ Depth $(\mathrm{cm})$} \\
\hline 0 & $73 \mathrm{~d}$ & $40 \mathrm{a}$ & $59 \mathrm{ab}$ & $58 \mathrm{ab}$ & $23 \mathrm{ab}$ & $22 \mathrm{ab}$ \\
\hline 2.5 & $69 \mathrm{c}$ & $44 \mathrm{a}$ & $64 \mathrm{bc}$ & $53 \mathrm{a}$ & $26 \mathrm{~b}$ & $19 \mathrm{a}$ \\
\hline 10 & $59 \mathrm{~b}$ & $54 \mathrm{~b}$ & $62 \mathrm{bc}$ & $54 \mathrm{ab}$ & $27 \mathrm{~b}$ & $18 \mathrm{a}$ \\
\hline SEM & \multicolumn{2}{|c|}{2} & \multicolumn{2}{|c|}{7} & \multicolumn{2}{|c|}{8} \\
\hline \multicolumn{7}{|l|}{ Tillage } \\
\hline $\mathrm{NT}^{\mathrm{c}}$ & $70 \mathrm{c}$ & $47 \mathrm{a}$ & $59 \mathrm{a}$ & $58 \mathrm{a}$ & $31 \mathrm{~b}$ & $24 \mathrm{ab}$ \\
\hline $\mathrm{CT}$ & $64 \mathrm{~b}$ & $46 \mathrm{a}$ & $65 \mathrm{a}$ & $52 \mathrm{a}$ & $20 \mathrm{ab}$ & $16 \mathrm{a}$ \\
\hline SEM & \multicolumn{2}{|l|}{8} & \multicolumn{2}{|c|}{7} & \multicolumn{2}{|c|}{8} \\
\hline
\end{tabular}

${ }^{a}$ Analyses were performed on $\operatorname{arcsine}(\mathrm{x})^{0.5}$-transformed values for seedbank persistence. Means appearing in Table 3 were back-transformed and multiplied by 100 to give percent persistence.

${ }^{\mathrm{b}}$ For a given species, factor means followed by the same lowercase letter are not significantly different $(\mathrm{P}>0.05)$ as determined by a Bonferronicorrected multiple comparison test.

c Explanation of abbreviations: NT, no till; CT, conventional tillage; SEM, standard error of the mean; IL, Urbana, IL; MI, Hickory Corners, MI; MN, Morris, MN.

$\mathrm{N}$ ratios may impede weed seed decay by soil microbes (Shem-Tov et al. 2005). The relatively low amount of variation explained by axis $2\left(\lambda_{2}=0.07\right)$ indicates that there were other important sources of variation in seedbank persistence across locations in addition to those measured here.

A sizeable portion of the unexplained variation across locations may have arisen from the numerous sources of experimental noise that plague multisite experiments, such as differences in management history of the experimental site, variation in maternal environment and quality of the various seed lots, the amount of time that seeds remained in cold storage before processing, slight variations in seed burial duration, and so forth.

\section{Location, Year, Tillage and Seed Depth Placement}

The minimum common data set available to examine the effects of burial location, primary tillage, seed depth placement, and burial year on weed seedbank persistence was limited to common lambsquarters, giant foxtail, and velvetleaf seed buried at Urbana, IL; Hickory Corners, MI; and Morris, MN. Analysis of variance within species showed strong interactions between burial year and location $(\mathrm{P}<$ $0.001)$, burial year and seed depth placement $(\mathrm{P}<0.001)$, and burial year and tillage $(\mathrm{P}<0.001)$. Bonferroni-corrected multiple comparison tests were used to explore the year by environment interaction effects (Table 3).

Seed persistence of common lambsquarters ranged from 5 to $95 \%$ across locations and years. It did not vary between years at Urbana, IL, and Morris, MN, but was substantially higher in 2001 than in 2002 at Hickory Corners, MI (Table 3). Seedbank persistence of velvetleaf ranged from 5 to $87 \%$. It did not vary between years at Urbana, IL, but was greater in 2001 than in 2002 at Hickory Corners, MI, and Morris, MN. Giant foxtail seedbank persistence ranged only from 8 to $45 \%$, which was about half that of the two broadleaf weeds. When averaged over depth and tillage treatment, giant foxtail seed persistence did not differ between years at any of the locations but tended to be greater at Urbana, IL, than at the other two locations in both years. Interestingly, averaged across years, seedbank persistence for giant foxtail was lowest in Morris, MN, where the plant does not grow naturally. The closest natural populations are about $150 \mathrm{~km}$ south and east of Morris.

Seed depth placement effects on seed persistence were inconsistent. In 2001, velvetleaf seed persistence decreased with depth, whereas in 2002, it increased with depth. Common lambsquarters and giant foxtail seedbank persistence were unaffected by depth within either year but were greater at the 2.5- and 10-cm depths in 2001 than in 2002. Although the effects of seed depth placement on seedling recruitment are well known (Benvenuti et al. 2001), the effects of depth placement on seed decay are not. The contrast in seedbank persistence between the soil surface and deeper soil layers in these data suggest that depth-related germination cues were driving the depth placement effects but because seedbank losses to seedling germination were confounded with those due to decay in this study, it is not possible to verify this assertion. The transient nature of the giant foxtail seedbank under all depths studied indicates that agronomic practices, such as complete inversion tillage, that place seed below the maximum burial depth from which recruitment is possible may help deplete seedbanks of this species.

Variance partitioning within species and burial years (Figure 4) offered an instructive comparison of the relative effects of location, seed burial depth, tillage, and unexplained sources of variation for the three species. The relative proportions of total variance explained by these variance components was similar both years. Approximately 20 to $40 \%$ of the variance for giant foxtail (Figure 4a) was explained by location, indicating that the relationship between seedbank persistence and hydrothermal time $\left(R^{2}=0.35\right.$ across locations) probably accounted for most of the variation in giant foxtail seedbank persistence due to location. Tillage and seed depth placement, factors under human control, explained another $10 \%$ of the variance in both years. However, 45 to $75 \%$ of the variance in giant foxtail seedbank persistence remained unexplained in 2001 and 2002, respectively. Clearly, other factors affecting giant foxtail seedbank persistence will need to be examined in controlled environment experiments.

The variance components for common lambsquarters (Figure 4b) and velvetleaf (Figure 4c) contrasted strongly with variance components for giant foxtail and were very similar to one another in each of the study years. Location effects explained from 70 to $90 \%$ of the variance in seedbank persistence for both species in 2001 and 2002, respectively. Although common lambsquarters and velvetleaf had significant negative linear relationships between seedbank persistence and hydrothermal time, these regressions did not explain a large proportion of the total variation. 


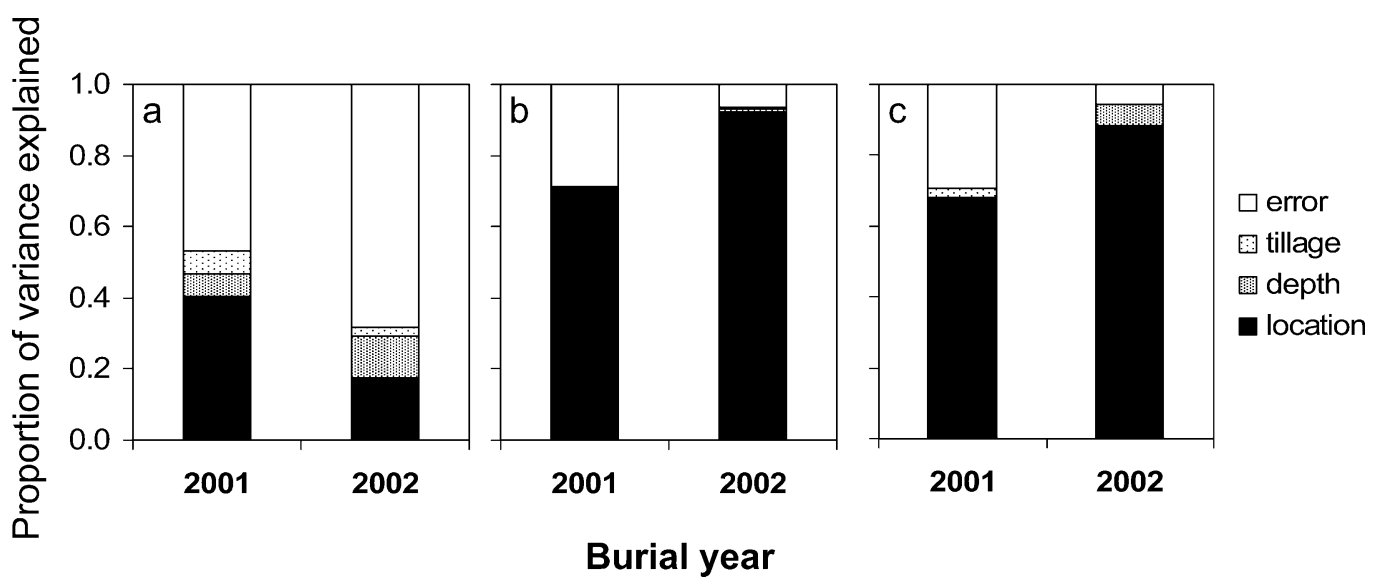

FIGURE 4. Variance proportions for tillage, seed burial depth, seed burial location, and pure error for giant foxtail (a), common lambsquarters (b), and velvetleaf (c) buried at Urbana, IL; Hickory Corners, MI; and Morris, MN, in 2001 and 2002.

This indicated that there were other factors associated with location that had important effects on seedbank persistence for these species but were unaccounted for in this study. One probable component of unexplained location effects is variation in maternal environmental conditions, such as daylength and temperature, during seed maturation. Variation in maternal environment can affect seed properties, such as seed coat permeability, seed dormancy, and seed germination requirements (Fenner and Thompson 2005), all of which may contribute to variation in seedbank persistence.

Tillage and seed depth placement accounted for under $5 \%$ of the variance in seedbank persistence for common lambsquarters and velvetleaf. One attribute of these species that may have contributed to the similarity in their variance components for seedbank persistence is that both are forbs with hard seeds and antimicrobial compounds in their seed coats as decay-resistance mechanisms (Kremer 1993). Overall, the variance partitioning results indicate that there may be considerably greater opportunity for managing seedbank persistence of giant foxtail than either common lambsquarters or velvetleaf, both of which were affected most by environmental conditions associated with burial location.

\section{Future Directions}

The data presented here provide estimates of both sitespecific and regional variability in seedbank persistence of several agronomic weeds. Hydrothermal time appeared to be a useful environmental variable for explaining seedbank persistence across locations, but it was unclear whether this relationship was driven by seedbank losses due to recruitment, decay, or both. Better methods are needed for partitioning the components of seedbank persistence. The buried bag method of seedbank study offers the advantage, in comparison to the seeded-core method (Teo-Sherrell et al. 1996), of easy seed recovery from the soil, but makes recording of seedling recruitment difficult. One possible improvement to this method would be to bury multiple seed bags as a composite experimental unit, removing bags on a regular basis during the growing season and recording cumulative recruitment from the location. Additional important information may be gleaned by treating seeds, seed bags, and adjacent soil with antimicrobial compounds.

Seedbank persistence is a major driver of weed population dynamics (Cousens and Mortimer 1995). Reducing weed seed viability in the soil has the potential to create large reductions in weed population growth rates (Gonzalez-Andujar and Fernandez-Quintanilla 1991; Jordan et al. 1995). Efforts to manage weed seedbanks for decreased persistence will benefit from studies that not only quantify rates of seedbank persistence, but develop methods of directly manipulating these rates.

\section{Sources of Materials}

${ }^{1}$ SYSTAT 11.0. 2004, SYSTAT Software, Inc., 501 Canal Boulevard, Richmond, CA 94804.

\section{Acknowledgments}

The authors gratefully acknowledge the many students and technicians who performed the hard work of characterizing several thousand seed lots for this study. Mention of trade names or commercial products in this article is solely for the purpose of providing scientific information and does not imply recommendation or endorsement by the U.S. Department of Agriculture.

\section{Literature Cited}

Benech-Arnold, R. L., R. A. Sanchez, F. Forcella, B. C. Kruck, and C. M. Ghersa. 2000. Environmental control of dormancy in weed seedbanks in soil. Field Crops Res. 67:105-122.

Benvenuti, S., M. Macchia, and S. Miele. 2001. Quantitative analysis of emergence of seedlings from buried weed seeds with increasing soil depth. Weed Sci. 49:528-535.

Bradford, K. 2002. Applications of hydrothermal time to quantifying and modeling seed germination and dormancy. Weed Sci. 50:248-260.

Buhler, D. D. and R. G. Hartzler. 2001. Emergence and persistence of seed of velvetleaf, common waterhemp, wooly cupgrass, and giant foxtail. Weed Sci. 49:230-235.

Burnside, O. C., R. G. Wilson, S. Weisberg, and K. G. Hubbard. 1996. Seed longevity of 41 weed species buried 17 years in eastern and western Nebraska. Weed Sci. 44:74-86.

Cousens, R. and M. Mortimer. 1995. Dynamics of Weed Populations. Cambridge, U.K.: Cambridge University Press. 332 p.

Davis, A. S., P. M. Dixon, and M. Liebman. 2004. Using matrix models to determine cropping system effects on annual weed demography. Ecol. Appl. 14:655-668.

Fenner, M. and K. Thompson. 2005. The Ecology of Seeds. Cambridge, U.K.: Cambridge University Press. 250 p.

Flerchinger, G. N. 2000. The Simultaneous Heat and Water (SHAW) Model: User's Manual. Northwest Watershed Research Center, U.S.D.A.A.R.S. Pp. 20. www.nwrc.ars.usda.gov/models/shaw/. 
Forcella, F., R. G. Wilson, J. Dekker, R. J. Kremer, J. Cardina, R. L. Anderson, D. Alm, K. A. Renner, G. Harvey, and S. Clay. 1997. Weed seedbank emergence across the corn belt. Weed Sci. 45:67-76.

Gallandt, E. R., E. P. Fuerst, and A. C. Kennedy. 2004. Effect of tillage, fungicide seed treatment, and soil fumigation on seedbank dynamics of wild oat (Avena fatua). Weed Sci. 52:597-604.

Gonzalez-Andujar, J. L. and C. Fernandez-Quintanilla. 1991. Modelling the population dynamics of Avena sterilis under dry-land cereal cropping systems. J. Appl. Ecol. 28:16-27.

Gotelli, N. J. and A. M. Ellison. 2004. A Primer of Ecological Statistics. Sunderland, MA: Sinauer. 150 p.

Grundy, A. C., K. Phelps, R. J. Reader, and S. Burston. 2000. Modelling the germination of Stellaria media using the concept of hydrothermal time. New Phytol. 148:433-444.

Harrison, S. K., E. E. Regnier, and J. T. Schmoll. 2003. Postdispersal predation of giant ragweed (Ambrosia trifida) in no-tillage corn. Weed Sci. 51:955-964.

Jordan, N., D. A. Mortensen, D. M. Prenzlow, and K. C. Cox. 1995. Simulation analysis of crop rotation effects on weed seedbanks. Am. J. Bot. 82:390-398.

Kremer, R. J. 1986. Antimicrobial activity of velvetleaf (Abutilon theophrasti) seeds. Weed Sci. 34:617-622.

Kremer, R. J. 1993. Management of weed seedbanks with microorganisms. Ecol. Appl. 3:42-52.

Lewis, J. 1973. Longevity of crop and weed seeds: survival after 20 years in soil. Weed Res. 13:179-191.

Neter, J., M. H. Kutner, C. J. Nachtsheim, and W. Wasserman. 1996. Applied Linear Statistical Models. Chicago: Irwin. 1408 p.

Økland, R. H. 1996. Are ordination and constrained ordination alternative or complementary strategies in general ecological studies? J. Veg. Sci. 7:289-292.
Peters, J., ed. 2000. Tetrazolium Testing Handbook. Contrib. No. 29 to the Handbook on Seed Testing. Lincoln, NE: Association of Official Seed Analysts.

Robertson, G. P., K. M. Klingensmith, M. J. Klug, E. A. Paul, J. R. Crum, and B. G. Ellis. 1997. Soil resources, microbial activity, and primary production across an agricultural ecosystem. Ecol. Appl. 7:158-170.

Schafer, M. and P. M. Kotanen. 2003. The influence of soil moisture on losses of buried seeds to fungi. Acta Oecol. 24:255-263.

Shem-Tov, S., S. Klose, H. A. Ajwa, and S. A. Fennimore. 2005. Effect of carbon:nitrogen ratio and organic amendments on seedbank longevity. Weed Sci. Soc. Am. Abstr. 45:97.

Tate, R.L.I. 1987. Soil Organic Matter: Biological and Ecological Effects. New York: Wiley Interscience. 318 p.

Taylor, K. L. and R. G. Hartzler. 2000. Effect of seedbank augmentation on herbicide efficacy. Weed Technol. 14:261-267.

Telewski, F. W. and J.A.D. Zeevaart. 2002. The 120-yr period for Dr. Beal's seed viability experiment. Am. J. Bot. 89:1285-1288.

Teo-Sherrell, C.P.A., D. A. Mortensen, and M. E. Keaton. 1996. Fates of weed seeds in soil: a seeded core method of study. J. Appl. Ecol. 33: 1107-1113.

ter Braak, C.J.F. and P. Smilauer. 2002. CANOCO Reference Manual and CanoDraw for Window's User's Guide: Software for Canonical Community Ordination (Version 4.5). Ithaca, NY: Microcomputer Power. $500 \mathrm{p}$.

Thompson, K., J. Bakker, and R. Bekker. 1997. The Soil Seedbanks of North West Europe: Methodology, Density and Longevity. Cambridge, U.K.: Cambridge University Press. 276 p.

Underwood, A. J. 1997. Experiments in Ecology: Their Design and Interpretation Using Analysis of Variance. Cambridge, U.K.: Cambridge University Press. 504 p.

Received May 31, 2005, and approved July 25, 2005. 